\title{
Calcium transport in diluted or cooled ram semen
}

\author{
L. Robertson and P. F. Watson \\ Department of Physiology, Royal Veterinary College, Royal College Street, \\ London NWI OTU, U.K.
}

\begin{abstract}
Summary. Ram semen was subjected to various dilution rates and temperatures of dilution, and was also subjected to slow cooling and rewarming. Calcium ion movements across sperm membranes were measured using the radioisotope ${ }^{45} \mathrm{Ca}^{2+}$. It was shown that even 2- to 4-fold dilution caused an increase in intracellular calcium content. An increase in intracellular calcium also occurred in proportion to a decreased temperature of dilution.

After an initial increase in intracellular calcium content, spermatozoa appeared able to restore a low intracellular calcium level over a period of $2 \mathrm{~h}$ at $22^{\circ} \mathrm{C}$ or above. This ability was lost at $16^{\circ} \mathrm{C}$ or below. However, if undiluted semen was slowly cooled $\left(0 \cdot 125^{\circ} \mathrm{C} / \mathrm{min}\right)$ even to $5^{\circ} \mathrm{C}$ and rewarmed to $22^{\circ} \mathrm{C}$ before dilution, the spermatozoa regained this ability. In contrast, spermatozoa rapidly cooled to $5^{\circ} \mathrm{C}$ and rewarmed to $22^{\circ} \mathrm{C}$ before dilution were not able to restore the low intracellular calcium level.
\end{abstract}

\section{Introduction}

The intracellular calcium level of spermatozoa is normally maintained at a low level until capacitation (Singh, Babcock \& Lardy, 1978). Ram spermatozoa subjected to rapid cooling, a phenomenon known as cold-shock and severely altering plasma membrane integrity, take up calcium into the cells (Quinn \& White, 1966; van Eerten \& Forrester, 1980). Moreover, cold-shocked ram spermatozoa, or even those subjected to less severe cooling regimens, also manifest biochemical and functional changes and a degree of membrane disruption in proportion to the cold stress (Watson, 1981). In this paper we consider the possibility that disturbances of intracellular calcium content might be an important component of the cellular dysfunction and structural disorganization. Accordingly, we have investigated the effects of dilution and cooling stresses less severe than that of cold shock to $0^{\circ} \mathrm{C}$ on the calcium influx in order to identify early changes in sperm cell membranes. Since it has been suggested that ram sperm membranes develop a resistance to cold shock over a period of incubation (Quinn, Salamon \& White, 1968), it was appropriate to investigate the effect of incubation on calcium movement in ram spermatozoa subjected to cold dilution. Some of the results have been published in abstract form (Plummer, Robertson \& Watson, 1986).

\section{Materials and Methods}

Ram semen was collected from Finnish Landrace rams by artificial vagina. Only samples with vigorous motility were used for the experiments. Sperm density was ascertained from light absorbance measurements on a previously calibrated colorimeter (Cox \& Melrose, 1953).

Except when dilution was a factor under investigation, semen was extended 10 -fold in a diluent containing $20 \mathrm{~mm}-\mathrm{Hepes}-\mathrm{NaOH}, 40 \mathrm{mM}-\mathrm{glucose}$ and $125 \mathrm{mM}-\mathrm{NaCl}(\mathrm{pH} 7 \cdot 0)$. Other dilutions were used as stated in 'Results'. In the dilution experiments, $\mathrm{CaCl}_{2}$ containing ${ }^{45} \mathrm{Ca}^{2+}$ with a specific activity of $0.1 \mu \mathrm{Ci} / \mathrm{ml}$ was added to the diluent giving a final calcium concentration of $0.3 \mathrm{mM}$. In 
the cold shock experiments, semen was diluted into Hepes-buffered glucose saline (HBGS) at the temperatures specified, while for the slow cooling experiments semen was cooled at $0.125^{\circ} \mathrm{C} / \mathrm{min}$ from $22^{\circ} \mathrm{C}$ to the temperatures specified before either dilution at the low temperature or rewarming to $22^{\circ} \mathrm{C}$ and dilution. Calcium movement was determined at intervals up to $2 \mathrm{~h}$ after dilution. Initial samples were removed immediately upon dilution. Calcium movement was terminated by mixing $100 \mu \mathrm{l}$ samples of diluted semen with $150 \mu \mathrm{l}$ HBGS containing 2 mM-EGTA-Tris, pH 7.0 at $4^{\circ} \mathrm{C}$ (Reed \& Bygrave, 1975). Sperm samples were separated from extracellular fluid by centrifugation through a silicon fluid layer comprising the supernatant from a 1:1 (v/v) mixture of DC 550 and DC 1107 (Dow Corning Corporation, Midland, MI, U.S.A.) centrifuged for $30 \mathrm{~min}$ at $1500 \mathrm{~g}$, prepared immediately before use. Semen samples $(250 \mu \mathrm{l})$ were pipetted onto a $100 \mu \mathrm{l}$ layer of the supernatant in $400 \mu$ l polyethylene microcentrifuge tubes and centrifuged at $1500 \mathrm{~g}$ for $2 \mathrm{~min}$. It had been previously established that $>99 \%$ of cells passed through the silicon layer under these conditions, leaving the extracellular fluid above the oil layer. The polyethylene tubes were cut through the oil layer and the tips containing the sperm plug were dropped into scintillation vials containing $3 \mathrm{ml}$ distilled water. The cells were resuspended by vortex mixing and $6 \mathrm{ml}$ Insta-gel scintillation fluid (Packard Instrument Company, Inc) were added. Samples were counted in triplicate for 10 min on a Packard Tri-carb Scintillation Spectrometer. A quenching curve demonstrated that $\sim 95 \%$ of the disintegrations per minute were estimated by the counter under these conditions and, therefore, the data were not corrected for system losses since all samples were treated identically. The data were converted to $\mathrm{nmol} \mathrm{Ca}^{2+} / 10^{9}$ spermatozoa.

Sperm motility was assessed by microscopic examination of drops of diluted semen under coverslips in random order at $37^{\circ} \mathrm{C}$. The percentage motile spermatozoa was estimated to the nearest $10 \%$ and the vigour of motility was scored on a scale of $0-4$ (Emmens, 1947). The differential stain, eosin-nigrosin, was used to estimate the percentage of living cells (Hancock, 1957). All data were subjected to analysis of variance; percentage data were transformed to angles before analysis.

\section{Results}

Subsamples of semen were diluted 10-fold in Hepes diluent containing $300 \mu \mathrm{M} \mathrm{CaCl}_{2}$ (Fig. 1). Radioactive calcium was added at the time of dilution or 1 or $2 \mathrm{~h}$ later. When the addition of

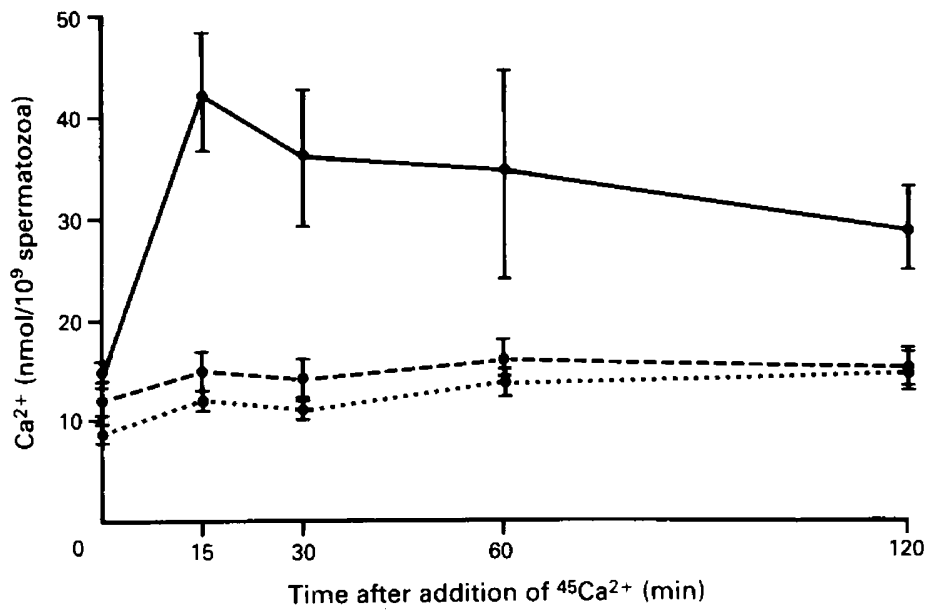

Fig. 1. Semen was diluted 10 -fold in Hepes-buffered glucose saline containing $300 \mu \mathrm{M}-\mathrm{CaCl}_{2}$ at $37^{\circ} \mathrm{C} .{ }^{45} \mathrm{Ca}^{2+}$ was added at dilution $(-), 1 \mathrm{~h}$ after dilution $(. .$.$) and 2 \mathrm{~h}$ after dilution $(---)$. 


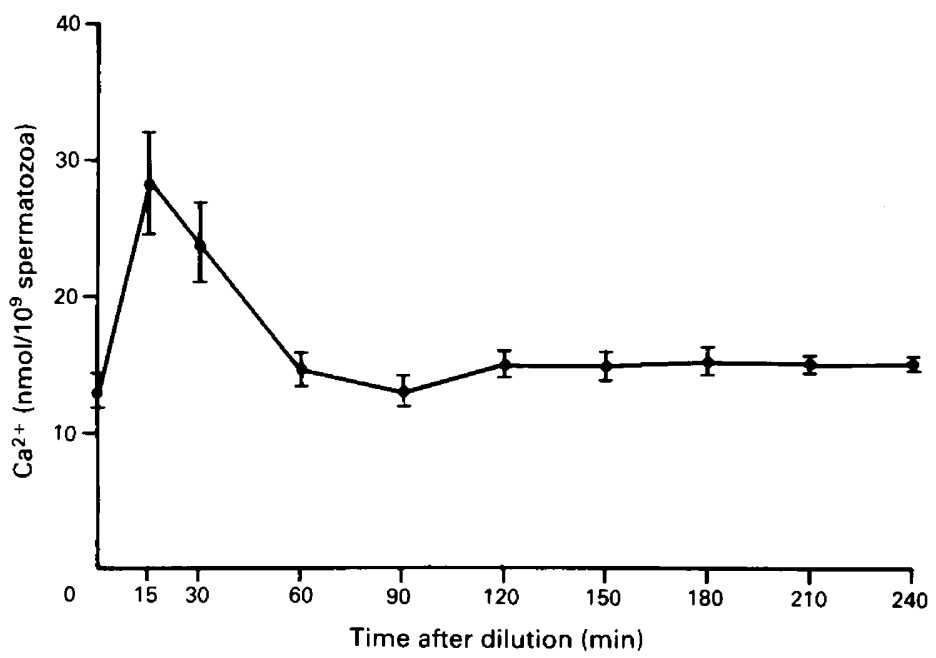

Fig. 2. Calcium movement over a 4 -h period after 10 -fold dilution at $37^{\circ} \mathrm{C}$.

${ }^{45} \mathrm{Ca}^{2+}$ coincided with dilution, an increase in intracellular calcium was observed which reached a maximum at $15 \mathrm{~min}$ and declined over the remainder of the 2-h period; there was no such increase when ${ }^{45} \mathrm{Ca}^{2+}$ was added later. In the treatments in which dilution had already occurred before ${ }^{45} \mathrm{Ca}^{2+}$ was added, initial values were similar to subsequent values suggesting that equilibration of ${ }^{45} \mathrm{Ca}^{2+}$ occurs rapidly in the period before the initial sample was taken.

Ram semen was diluted 10 -fold in Hepes-buffered glucose saline containing ${ }^{45} \mathrm{Ca}^{2+}$ in $300 \mu \mathrm{M}$ $\mathrm{CaCl}_{2}$ and incubated at $37^{\circ} \mathrm{C}$ for $4 \mathrm{~h}$ (Fig. 2). There was an increase in intracellular calcium content during the first $15 \mathrm{~min}$ after dilution which returned to the level of the initial sampling time by $60 \mathrm{~min}$ and remained stable at that level for the next $3 \mathrm{~h}$.

Ram semen was diluted 2-, 4-, 8- or 16 -fold into the diluent containing ${ }^{45} \mathrm{Ca}^{2+}$ at $37^{\circ} \mathrm{C}$, and the intracellular calcium content measured (Table 1). The calcium content rose to a maximum 15-30 min after dilution but was restored to low levels by $2 \mathrm{~h}$. The magnitude of the increase was related to the degree of dilution reaching a maximum of $>140 \mathrm{nmol} \mathrm{Ca}^{2+} / 10^{9}$ spermatozoa in the 16-fold dilution; the treatments differed significantly at $60 \mathrm{~min}(P<0.001)$. Although the sperm calcium content was significantly altered by dilution no decline in either the motility or in the percentage of cells unstained by eosin could be detected until the dilution rate exceeded 32-fold (Table 2).

Table 1. Intracellular calcium content (nmol $\mathrm{Ca}^{2+} / 10^{9}$ spermatozoa) after dilution of ram semen to various ratios (semen:diluent)

\begin{tabular}{lrrrr}
\hline $\begin{array}{l}\text { Time after } \\
\text { dilution } \\
\text { (min) }\end{array}$ & \multicolumn{5}{c}{ Dilution ratio } \\
\cline { 2 - 5 } & \multicolumn{1}{c}{$1: 2$} & \multicolumn{1}{c}{$1: 4$} & \multicolumn{1}{c}{$1: 8$} & \multicolumn{1}{c}{$1: 16$} \\
\hline 0 & $48 \cdot 0 \pm 6 \cdot 4$ & $61 \cdot 0 \pm 6 \cdot 8$ & $38 \cdot 6 \pm 9 \cdot 7$ & $30 \cdot 2 \pm 4 \cdot 6$ \\
15 & $78 \cdot 6 \pm 11 \cdot 8$ & $88 \cdot 0 \pm 7 \cdot 8$ & $112 \cdot 0 \pm 12 \cdot 3$ & $141 \cdot 0 \pm 20 \cdot 8$ \\
30 & $96 \cdot 8 \pm 10 \cdot 3$ & $107 \cdot 6 \pm 6 \cdot 8$ & $116 \cdot 0 \pm 16 \cdot 7$ & $135 \cdot 0 \pm 19 \cdot 8$ \\
60 & $35 \cdot 4 \pm 2 \cdot 4$ & $62 \cdot 0 \pm 3 \cdot 5$ & $85 \cdot 9 \pm 9 \cdot 6$ & $113.0 \pm 5 \cdot 2$ \\
120 & $45 \cdot 4 \pm 2 \cdot 5$ & $47 \cdot 2 \pm 2 \cdot 8$ & $41 \cdot 4 \pm 4 \cdot 2$ & $56 \cdot 5 \pm 7 \cdot 2$ \\
\hline
\end{tabular}

*Values are means of 3 pooled samples ( 2 ejaculates/sample) \pm s.e.m. 
Table 2. Characteristics of ram spermatozoa diluted 8-, 16-, 32- and 64-fold in Hepes-buffered glucose saline

\begin{tabular}{lcccc}
\hline & \multicolumn{4}{c}{ Dilution } \\
\cline { 2 - 5 } Characteristic* & \multicolumn{1}{c}{$1: 8$} & $1: 16$ & $1: 32$ & $1: 64$ \\
\hline \% Motile & $78 \cdot 0 \pm 2.5$ & $72.0 \pm 3 \cdot 0$ & $70.0 \pm 3.5$ & $49 \cdot 0 \pm 12.0$ \\
Motility & $3.95 \pm 0.05$ & $3.7 \pm 0 \cdot 09$ & $3.65 \pm 0.23$ & $2.65 \pm 0.7$ \\
$\%$ Live & $88.0 \pm 1.9$ & $82.2 \pm 2.9$ & $82.0 \pm 1.6$ & $77.6 \pm 8.7$ \\
\hline
\end{tabular}

*Motility scored on a scale of $0-4$ and percentage live estimated using eosin-nigrosin differential staining $30 \mathrm{~min}$ after dilution.

Values are means of 6 ejaculates \pm s.e.m.

The rise in intracellular calcium content of ram spermatozoa diluted 10 -fold at temperatures of 37,30 and $22^{\circ} \mathrm{C}$, and 22,16 and $8^{\circ} \mathrm{C}$ was compared. Results over $2 \mathrm{~h}$ after dilution are shown in Fig. 3. After dilution at 37,30 and $22^{\circ} \mathrm{C}$ there was an increase in the intracellular calcium content over the first 15-30 min, the greatest increase being associated with the lowest temperature; by $2 \mathrm{~h}$ after dilution this increase in calcium content had been reversed. In contrast, below $22^{\circ} \mathrm{C}$ (Fig. $3 \mathrm{~b}$ ) there was a large increase in intracellular calcium content in the first hour which remained high or increased further during the second hour after dilution, with the highest values consistently being

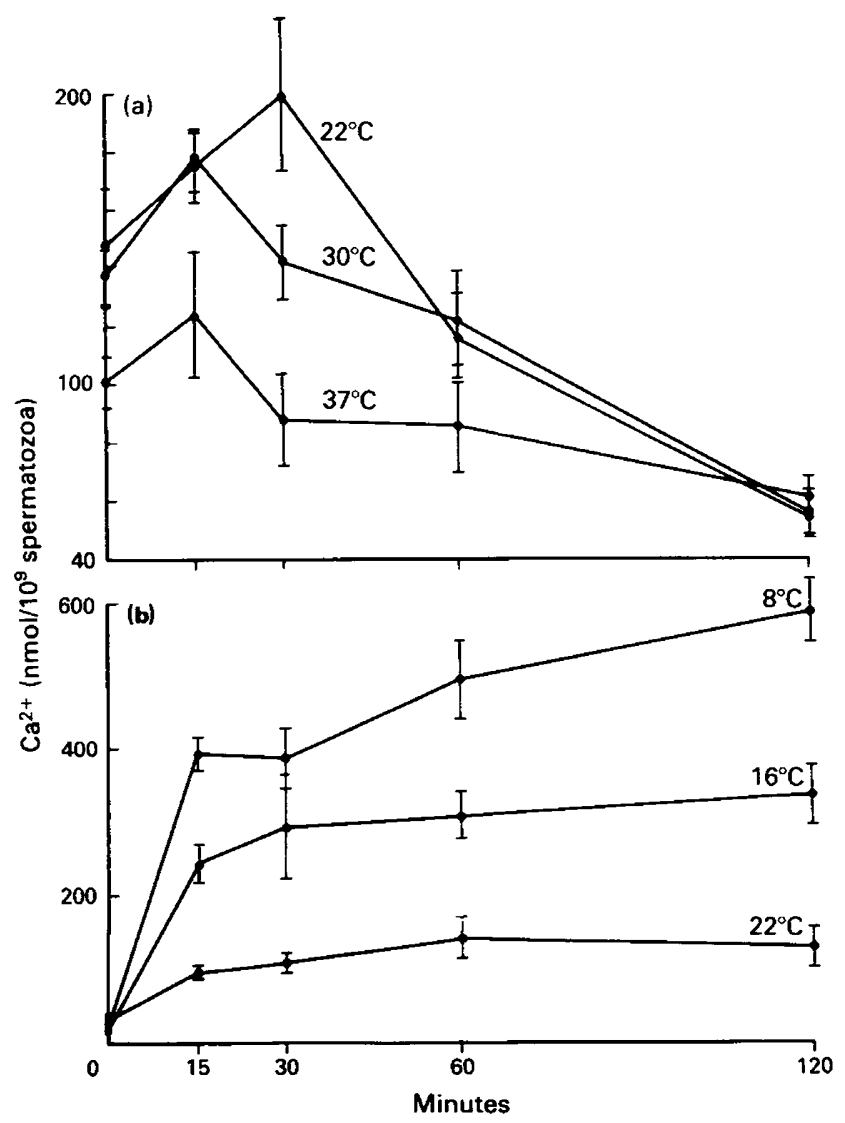

Fig. 3. Calcium movement over 2 -h period after dilution at (a) 37,30 and $22^{\circ} \mathrm{C}$, and (b) 22,16 and $8^{\circ} \mathrm{C}$. 
Table 3. Comparison of intracellular calcium content (nmol $\mathrm{Ca}^{2+} / 10^{9}$ spermatozoa) of spermatozoa rapidly cooled to $16^{\circ} \mathrm{C}$ and those slowly cooled to $16^{\circ} \mathrm{C}$

\begin{tabular}{lcc}
\hline $\begin{array}{l}\text { Time after } \\
\text { dilution } \\
\text { (min) }\end{array}$ & Rapidly cooled & Slowly cooled \\
\hline 0 & $23 \cdot 7 \pm 5 \cdot 6$ & $17 \cdot 6 \pm 3 \cdot 8$ \\
15 & $79 \cdot 7 \pm 13 \cdot 5$ & $57 \cdot 6 \pm 4 \cdot 8$ \\
30 & $126 \cdot 0 \pm 19 \cdot 0$ & $81 \cdot 8 \pm 7 \cdot 3$ \\
60 & $174 \cdot 0 \pm 21 \cdot 2$ & $126 \cdot 0 \pm 12 \cdot 0$ \\
120 & $235 \cdot 0 \pm 30 \cdot 6$ & $191 \cdot 0 \pm 22 \cdot 2$ \\
\hline
\end{tabular}

Values are means of 6 ejaculates \pm s.e.m.

associated with the lowest temperature. Significant differences $(P<0.001)$ were recorded between treatments as early as 15 min after dilution.

In view of the different response of spermatozoa to cooling below and above $22^{\circ} \mathrm{C}$, the influence of cold shock was considered. Fresh undiluted semen was cooled slowly from 23 to $16^{\circ} \mathrm{C}$ at $0.125^{\circ} \mathrm{C} / \mathrm{min}$, and then diluted 10 -fold at that temperature in a diluent containing $0.3 \mathrm{mM} \cdot \mathrm{CaCl}_{2}$ with ${ }^{45} \mathrm{Ca}^{2+}$. The resulting increase in intracellular calcium content over a $2-\mathrm{h}$ period was compared with that of semen from the same ejaculate held at $23^{\circ} \mathrm{C}$ and diluted into diluent at $16^{\circ} \mathrm{C}$ (sudden cooling). The results are shown in Table 3. Although the rise in calcium content was greater in the rapidly cooled samples compared to the slowly cooled samples $(P<0.001)$, in neither treatment were the spermatozoa able to restore the increase in calcium levels within $2 \mathrm{~h}$ of dilution.

In contrast, when undiluted semen samples were cooled slowly or rapidly (Fig. 4) to $16^{\circ} \mathrm{C}$ and

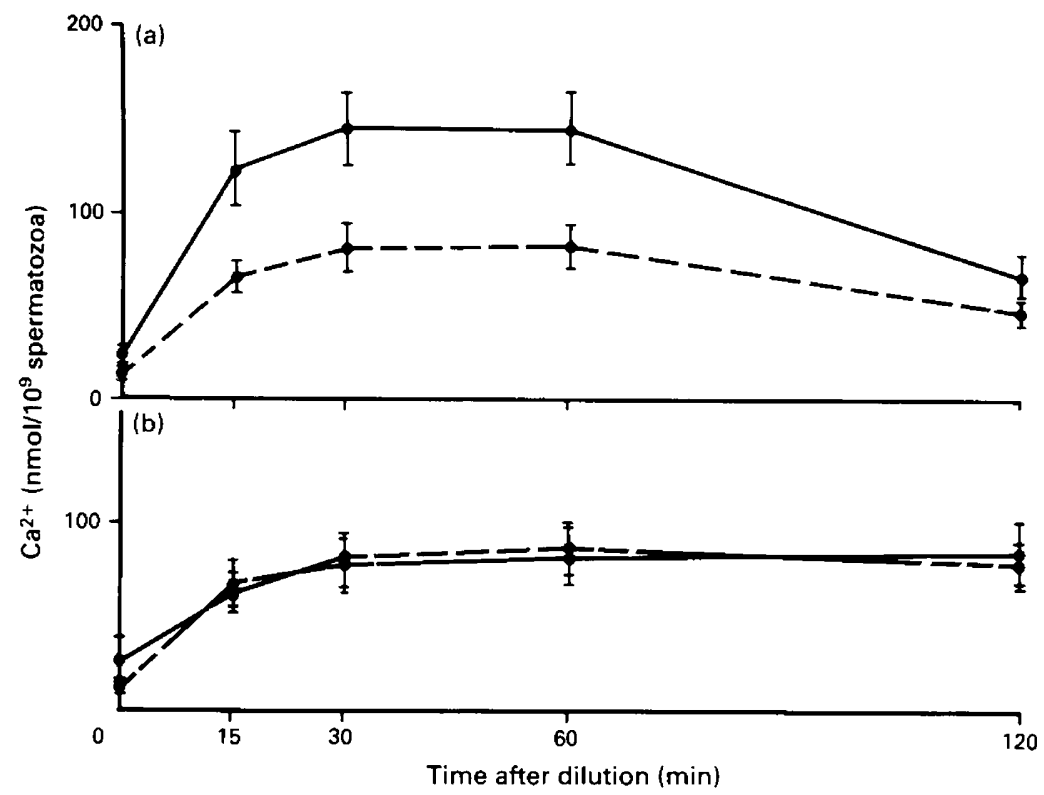

Fig. 4. The effect of rapid and slow cooling of undiluted semen to $16^{\circ} \mathrm{C}$ and rewarming to $22^{\circ} \mathrm{C}$ on calcium movement over the 2 -h period after dilution at $22^{\circ} \mathrm{C}$. (a) Control samples held at and diluted at $22^{\circ} \mathrm{C}(---)$ and rapid cooling by immersion of sample in a waterbath at $16^{\circ} \mathrm{C}$, rewarming to and dilution at $22^{\circ} \mathrm{C}(-)$. (b) Control samples held at and diluted at $22^{\circ} \mathrm{C}$ $(--)$ and slow cooling to $16^{\circ} \mathrm{C}$ at $0 \cdot 125^{\circ} \mathrm{C} / \mathrm{min}$, rewarming to and diluting at $22^{\circ} \mathrm{C}(-)$. 


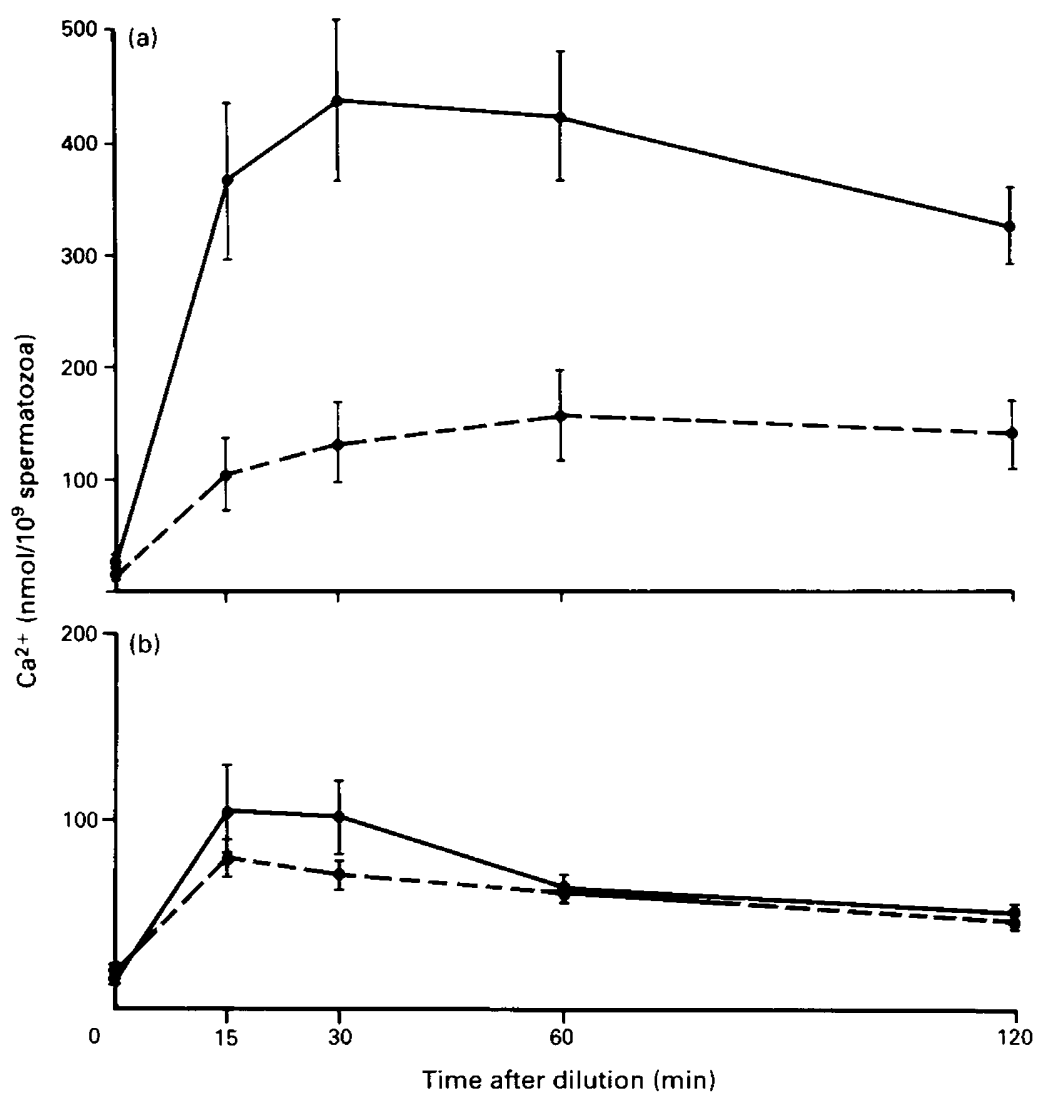

Fig. 5. The effect of rapid and slow cooling of undiluted semen to $5^{\circ} \mathrm{C}$ and rewarming to $22^{\circ} \mathrm{C}$ on the calcium movement over the 2 -h period after dilution at $22^{\circ} \mathrm{C}$. (a) Control samples diluted at $22^{\circ} \mathrm{C}(---)$ and undiluted semen rapidly cooled to $5^{\circ} \mathrm{C}$, rewarmed to $22^{\circ} \mathrm{C}$, diluted and incubated for $2 \mathrm{~h}$ at $22^{\circ} \mathrm{C}(-)$. (b) Control samples held at and diluted at $22^{\circ} \mathrm{C}(---)$ and undiluted semen slowly cooled to $5^{\circ} \mathrm{C}$ at $0 \cdot 125^{\circ} \mathrm{C} / \mathrm{min}$, before rapid rewarming and dilution at $22^{\circ} \mathrm{C}(-)$.

then rewarmed to $22^{\circ} \mathrm{C}$ before dilution, the intracellular calcium level did not continue to rise in the second hour after dilution. The rapidly cooled samples showed a significantly greater peak value at $30-60$ min compared with control samples from the same ejaculates incubated and diluted at $22^{\circ} \mathrm{C}$, but the cooled cells were still able to contain the increase in calcium ions.

Spermatozoa rapidly cooled to $5^{\circ} \mathrm{C}$, and rewarmed to $22^{\circ} \mathrm{C}$ before dilution were unable to contain the increase in intracellular calcium content over a 2 -h incubation period and were significantly different from controls diluted and incubated at $22^{\circ} \mathrm{C}$ for $2 \mathrm{~h}$ (Fig. 5a). The difference was significant from $15 \mathrm{~min}(P<0.001)$. However, when undiluted spermatozoa carefully cooled to $5^{\circ} \mathrm{C}$ at $0.125^{\circ} \mathrm{C} / \mathrm{min}$ were rapidly warmed and diluted at $22^{\circ} \mathrm{C}$ there were no significant differences between these spermatozoa and their controls incubated at $22^{\circ} \mathrm{C}$ during the period of cooling (Fig. $5 \mathrm{~b}$ ).

In the previous two experiments control samples were incubated for various periods at $22^{\circ} \mathrm{C}$ before dilution. As it has been suggested that ram sperm membranes develop a resistance to cold shock with time, the effect of holding at $22^{\circ} \mathrm{C}$ before dilution was investigated. The results (Table 4) revealed that the increase in intracellular calcium content which occurred at dilution was significantly diminished by a holding period of $2 \mathrm{~h}(P<0.001)$. 
Table 4. The effect on intracellular calcium content (nmol $\mathrm{Ca}^{2+} / 10^{9}$ spermatozoa) of holding ram semen samples at $22^{\circ} \mathrm{C}$ for different periods of time before dilution at $12^{\circ} \mathrm{C}$

\begin{tabular}{lrrr}
\hline \multirow{2}{*}{$\begin{array}{l}\text { Time after } \\
\text { dilution } \\
\text { (min) }\end{array}$} & \multicolumn{4}{c}{ Incubation before dilution (h) } \\
\cline { 2 - 4 } & \multicolumn{1}{c}{0} & \multicolumn{1}{c}{1} & \multicolumn{1}{c}{2} \\
\hline 0 & $14 \cdot 9 \pm 1 \cdot 7$ & $12 \cdot 8 \pm 0 \cdot 2$ & $13 \cdot 8 \pm 1 \cdot 7$ \\
15 & $184 \cdot 0 \pm 25 \cdot 0$ & $218 \cdot 0 \pm 29 \cdot 0$ & $125 \cdot 0 \pm 20 \cdot 0$ \\
30 & $302 \cdot 0 \pm 36 \cdot 1$ & $220 \cdot 0 \pm 31 \cdot 0$ & $189 \cdot 0 \pm 30 \cdot 0$ \\
60 & $511 \cdot 0 \pm 65 \cdot 6$ & $339 \cdot 0 \pm 40 \cdot 8$ & $225 \cdot 0 \pm 39 \cdot 4$ \\
120 & $435 \cdot 0 \pm 56 \cdot 0$ & $330 \cdot 0 \pm 53 \cdot 0$ & $151 \cdot 0 \pm 44 \cdot 4$ \\
\hline
\end{tabular}

Values are means of 6 ejaculates \pm s.e.m.

\section{Discussion}

After addition of ${ }^{45} \mathrm{Ca}^{2+}$ a brief time elapses during which equilibration is occurring across the plasma membrane. Thereafter, further movement of ${ }^{45} \mathrm{Ca}^{2+}$ will reflect net changes in intracellular calcium. In the first experiment, it was demonstrated that the rise and fall of calcium over the first $2 \mathrm{~h}$ occurred only upon dilution and was not associated with the addition of ${ }^{45} \mathrm{Ca}^{2+}$. In some experiments, occasional treatments had elevated initial values most probably reflecting the rapid rate of uptake in damaged cells and/or a brief delay in initial sampling.

The amount of intracellular calcium accumulated by diluted ram spermatozoa increased with the dilution rate. That this is not simply reflecting a change in cell volume is shown by the magnitude of the changes involved; a $374 \%$ increase in volume $60 \mathrm{~min}$ after 16 -fold dilution would be very obvious and was not evident. The results therefore indicate that even low dilution of ram semen caused a temporary but real increase in intracellular calcium concentration. This observation implies that other studies of intracellular calcium content which have involved washing the cells before measurement (Quinn \& White, 1966; Karagiannidis, 1976) may have overestimated the normal intracellular calcium levels. It is also pertinent that this increase in intracellular calcium content was evident at dilution rates lower than those that affected motility and differential staining ( $>$ 32-fold dilution). Peak intracellular calcium levels were attained about 30 min after dilution and the levels were restored to initial values over the next $90 \mathrm{~min}$. Further studies (Fig. 2) showed that the intracellular calcium content remained stable thereafter during incubation for at least $4 \mathrm{~h}$. That the initial value resembled values over $2-4 \mathrm{~h}$ after dilution suggested very rapid equilibration. The subsequent rise over $30 \mathrm{~min}$ probably represents accumulation in various intracellular compartments or pools. It is well recognized that calcium gaining intracellular access to spermatozoa is accumulated by mitochondria (Babcock, First \& Lardy, 1976; Babcock, Stamerjohn \& Hutchinson, 1978; van Eerten \& Forrester, 1980).

The magnitude of the increase in intracellular calcium content was temperature-dependent, as was the ability of the cell to extrude the calcium load. Below $22^{\circ} \mathrm{C}$, ram spermatozoa showed a reduced ability to cope with the calcium load and this effect was magnified at lower temperatures, resulting in a steady accumulation of calcium. Cooling of a calcium-dependent ATPase in the sperm plasma membrane would undoubtedly contribute to this effect. Holt \& North (1985) demonstrated a change in the slope of the Arrhenius plot of calcium-stimulated ATPase activity in ram sperm flagellar membranes at about $23-24^{\circ} \mathrm{C}$ and interpreted this as indicating a thermal phase transition in membrane lipids in the vicinity of the ATPase molecules. As a consequence of phase transitions in membranes it is believed that lateral phase separations occur, resulting in the exclusion of intrinsic proteins into fluid regions and the formation of crystalline lipid domains intersected by packing faults; as a result, permeability may increase and the aggregation of proteins may interfere with metabolic functions such as ion transport (Pringle \& Chapman, 1981). Therefore 
phase changes and temperature inhibition of the calcium pump should both be considered as potentially contributing to loss of the ability of the cell to regulate intracellular calcium.

Rapid cooling resulted in a greater increase in intracellular calcium than occurred with slow cooling. However, when the spermatozoa were cooled only to $16^{\circ} \mathrm{C}$ the cells were subsequently able to restore calcium levels when rewarmed to $22^{\circ} \mathrm{C}$, irrespective of cooling rate. On the other hand, spermatozoa cooled to $5^{\circ} \mathrm{C}$ and rewarmed showed a clear difference in their ability to control intracellular calcium levels depending upon the rate of cooling; cold shocked spermatozoa exhibited an inability to reverse the calcium accumulation while slowly cooled and rewarmed cells were as able as uncooled cells to control calcium levels. If the cooling stress were not too great, therefore, there was a temporary arrest of membrane function at the reduced temperature, but a more severe cold stress resulted in an irreversible loss of the ability to regulate calcium.

The reversible changes with cooling could be accounted for in terms of inhibition of energydependent processes and/or a transient increase in permeability, whereas the permanent alteration of membrane function suggests a loss of integrity. Spermatozoa incubated after ejaculation acquired a degree of resistance to cold shock as revealed by motility and vital staining (Quinn et al., 1968). In the present study it was shown that the accumulation of calcium during cold shock was reduced in incubated spermatozoa, perhaps because of a greater resistance to membrane damage in such cells. These results lend support to the view that the calcium entry is occasioned by increased permeability. Certainly, severely cold-shocked ram spermatozoa show extensive membrane damage involving not only the plasma membrane but also the acrosome, but the extent of the disruption is not easily explained in terms of lipid-phase separations (Watson, 1981). However, in view of the crucial role of calcium ions in the acrosome reaction (Yanagimachi \& Usui, 1974; Shams-Borham \& Harrison, 1981) it is possible that, should the plasma membrane barrier be breached, the access of calcium to the outer acrosomal membrane is sufficient to induce further membrane disruption. In those experiments in which permanent membrane damage was observed, the intracellular calcium levels were considerably higher than those in which the change was transient. Plummer \& Watson (1985) have demonstrated calcium bound to the outer acrosomal membrane in cold-shocked ram spermatozoa when the plasma membrane was damaged. Moreover, the divalent ion chelator, EDTA, markedly reduced both calcium accumulation and loss of motility in cold-shocked ram spermatozoa (Quinn \& White, 1968). These observations lend support to the view that calcium ions may be a factor in extending the membrane damage commenced by cold shock.

\section{L.R. was supported by an AFRC Veterinary Schools Fellowship.}

\section{References}

Babcock, D.F., First, N.L. \& Lardy, H.A. (1976) Action of ionophore A23187 at the cellular level. J. biol. Chem. 251, 3881-3886.

Babcock, D.F., Stamerjohn, D.M. \& Hutchinson, T. (1978) Calcium redistribution in individual cells correlated with ionophore action on motility. J. exp. Zool. 204, 391-400.

Cox, C.P. \& Melrose, D.R. (1953) The calibration of a photo-electric absorptiometer for the rapid estimation of counts of spermatozoa in bull semen. J. agric. Sci., Camb. 43, 375-379.

Emmens, C.W. (1947) The motility and viability of rabbit spermatozoa at different hydrogen-ion concentrations. J. Physiol., Lond. 106, 471-481.

Hancock, J.L. (1957) The morphology of boar spermatozoa. Jl R. micros. Soc. 76, 84-97.
Holt, W.V. \& North, R.D. (1985) Determination of lipid composition and thermal phase transition temperature in an enriched plasma membrane fraction from ram spermatozoa. J. Reprod. Fert. 73, 285-295.

Karagiannidis, A. (1976) The distribution of calcium in bovine spermatozoa and seminal plasma in relation to cold shock. J. Reprod. Fert. 46, 83-90.

Plummer, J.M. \& Watson, P.F. (1985) Ultrastructural localization of calcium ions in ram spermatozoa before and after cold shock as demonstrated by a pyroantimonate technique. $J$. Reprod. Fert. 75, 255-263.

Plummer, J.M., Robertson, L. \& Watson, P.F. (1986) Calcium ion movement across the plasma membrane of ram spermatozoa subjected to mild cold stress. $J$. Physiol., Lond. (in press). 
Pringle, M.J. \& Chapman, D. (1981) Biomembrane structure and effects of temperature. In Effects of Low Temperatures on Biological Membranes, pp. 21-37. Eds G. J. Morris \& A. Clark. Academic Press, London.

Quinn, P.J. \& White, I.G. (1966) The effect of cold shock and deep freezing on the concentration of major cations in spermatozoa. J. Reprod. Fert. 12, 263-270.

Quinn, P.J. \& White, I.G. (1968) The effects of pH, cations and protective agents on the susceptibility of ram spermatozoa to cold shock. Expl Cell Res. 49, 31-39.

Quinn, P.J., Salamon, S. \& White, I.G. (1968) The effect of cold shock and deep-freezing on ram spermatozoa collected by electrical ejaculation and by an artificial vagina. Aust. J. agric. Res. 19, 119-128.

Reed, K.C. \& Bygrave, F.L. (1975) Methodology for in vitro studies of $\mathrm{Ca}^{++}$transport. Analyt. Biochem. 67, 44-54.
Shams-Borham, G. \& Harrison, R.A.P. (1981) Production, characterization and use of ionophore-induced, calcium-dependent acrosome reaction in ram spermatozoa. Gamete Res. 4, 407-432.

Singh, J.P., Babcock, D.F. \& Lardy, H.A. (1978) Increased calcium-ion influx is a component of capacitation of spermatozoa. Biochem. J. 172 , 549-556.

van Eerten, M.T.W. \& Forrester, I.T. (1980) Biochemical aspects of ram sperm viability. Proc. N.Z. Soc. Anim. Prodn 40, 130-135.

Watson, P.F. (1981) The effects of cold shock on sperm cell membranes. In Effects of Low Temperatures on Biological Membranes, pp. 189-218. Eds G. J. Morris \& A. Clark. Academic Press, London.

Yanagimachi, R. \& Usui, N. (1974) Calcium dependence of the acrosome reaction and activation of guinea-pig spermatozoa. Expl Cell Res. 89, 161-174.

Received 23 August 1985 